\section{PATHOGENESIS, MODULATION, AND THERAPY OF ALZHEIMER'S DISEASE: A PERSPECTIVE ON ROLES OF LIVER-X RECEPTORS}

Abstract

The pathogenesis of Alzheimer's disease (AD) has been mostly linked to aberrant amyloid beta $(A \beta)$ and tau proteins metabolism, disturbed lipid/cholesterol homeostasis, and progressive neuroinflammation. Liver $\mathrm{X}$ receptors (LXR) are ligand-activated transcription factors, best known as the key regulators of cholesterol metabolism and transport. In addition, LXR signaling has been shown to have significant anti-inflammatory properties. In this brief review, we focus on the outcome of studies implicating LXR in the pathogenesis, modulation, and therapy of AD.

Keywords - Alzheimer's disease $\cdot$ Neurodegeneration $\cdot$ Amyloid-beta $\cdot$ Cholesterol $\cdot$ Liver-X receptors $\cdot$ LXR agonists $\cdot$ Neuroinflammation $\cdot$ Transgenic mouse models

(c) Versita Sp. z o.o.
Jasminka Štefulj $j^{1,2, *}$

Ute Panzenboeck ${ }^{3}$,

Patrick R. Hof ${ }^{4}$,

Goran Šimić ${ }^{5}$

'Laboratory of Neurochemistry and Molecular Neurobiology, Department of Molecular Biology, Ruđer Bošković Institute, Zagreb, Croatia

${ }^{2}$ Croatian Catholic University, Zagreb,

Croatia

${ }^{3}$ Institute of Pathophysiology and Immunology, Medical University of Graz, Graz, Austria

${ }^{4}$ Fishberg Department of Neuroscience and Friedman Brain Institute, Icahn School of Medicine at Mount Sinai, New York, U.S.A. ${ }^{5}$ Department for Neuroscience, Croatian Institute for Brain Research, University of Zagreb Medical School, Zagreb, Croatia

Received 15 August 2013 accepted 31 August 2013

\section{Introduction}

Alzheimer's disease (AD) accounts for about $55-70 \%$ of adult-onset dementia in the industrialized world [1] and is the fifth leading cause of death in the USA in people older than 65 [2]. A number of risk factors for $A D$ have been identified, such as hypertension, hyperlipidemia, cardiovascular disease, diabetes mellitus, and obesity [3]. However, $A D$ etiopathogenesis still remains poorly understood. Relatively rare familial forms of $A D$ have been linked to mutations in amyloid precursor protein (APP), presenilin 1 (PSEN1) or presenilin 2 (PSEN2) genes, while genetic risk factors for the more prevalent sporadic $A D$ are much less clear $[4,5]$. Several key components of $A D$ pathogenesis have been well identified and characterized, including aberrant amyloidbeta peptide $(A \beta)$ [6] and tau metabolism [7], disturbed lipid/cholesterol homeostasis [8], and progressive neuroinflammation [9]. However, despite decades of intensive research on many aspects of the disease, $A D$ remains an unpreventable and life-threatening condition with no effective treatments for either curing it or slowing its progression [10].

Liver-X receptors (LXR) are members of the large superfamily of nuclear receptors (NR) that share similar functions and conserved molecular structure [11]. These proteins, classified as transcription factors, directly interact with the regulatory DNA sequences and upon activation by binding of agonists to their ligand binding domains, modulate transcription of the target genes. The two LXR isoforms, LXRa and LXRß (known also as NR1H3 and $\mathrm{NR} 1 \mathrm{H} 2$, respectively) were discovered between 1994-1995 based on the sequence homology with other NR $[12,13]$. LXRa, initially isolated from a rat liver CDNA library as a novel NR with unknown physiological ligands (hence the name "liver-X receptor") is found at high levels in cholesterol-metabolizing tissues, while LXR $\beta$ is ubiquitously expressed. Natural (endogenous) ligands for both LXR isoforms are oxysterols, the most potent of which are 24(S)hydroxycholesterol, 27-hydroxycholesterol 22(R)-hydroxycholesterol, and 24(S),25- epoxycholesterol [12]. Many of the LXR target genes, including ATP-binding cassette transporters $A 1$ (ABCA1) and $G 1$ (ABCG1), apolipoprotein $E$ (apoE), apolipoprotein $M$ (apoM), phospholipid transfer protein (PLTP) and several other proteins, have been shown to be centrally involved in cholesterol transport and metabolism in various tissues and cell types. Hence, LXRs are best known as the master transcriptional regulators of cellular and whole-body cholesterol/lipid homeostasis [14-17]. In addition, LXRs have been also implicated in the regulation of immune response [18] and carbohydrate metabolism [19].

Due to the ability to integrate metabolic and immune signaling, LXR have been recognised as attractive therapeutic targets for chronic metabolic and/or inflammatory diseases as diverse as atherosclerosis, dyslipidaemia, and cancer [20]. There is increasing evidence linking LXR to pathogenesis and modulation of neurodegenerative disorders, including AD. Several LXR-controlled genes have been reported to be dysregulated in the brains of $A D$ patients [21-24] and overexpression or 
deletion of some LXR target genes in animal models of $A D$ has been shown to alter $A D$ related pathology [25-27]. Here we briefly outline genetic and pharmacological studies linking $L X R$ to $A D$, and delineate $L X R$-regulated pathways that could possibly modulate the outcome of this devastating disease (Figure 1).

2. GENETIC IMPLICATING LXRS IN
NEURODEGENERATION AND PATHOGENESIS OF AD

\subsection{LXR knockout mice}

The first evidence for the roles of LXR in neurodegeneration came from a study examining the neurological phenotype of mice with inactivated genes of both LXR isoforms [28]. Brains of these animals display several severe abnormalities including excessive lipid deposits, morphological changes of blood vessels and choroid plexus, proliferation of astrocytes, loss of neurons, and disorganisation of myelin sheets. Furthermore, mice with selective inactivation of the LXR $\beta$ isoform were shown to suffer from impaired motor coordination [29] and reduced number of neurons in the superficial cortical layers [30]. Zelcer et al. [31] reported that loss of either LXRa or LXR $\beta$ in a mouse model of $A D$ aggravates $A D$-related pathology, i.e. increases $A \beta$ plaque load in the brain tissue, while Terwell et al. [32] demonstrated that lack of $L X R a$ impairs $A \beta$ phagocytosis in $A D$ mice. Deleterious effects of LXR inactivation have been shown also in mouse models of NiemannPick type C disease (NPC), a monogenic neurodegenerative disorder associated with intracellular lipid/cholesterol accumulation [33]. Taken together, LXR-knockout studies clearly show that LXR have important roles in brain physiology and suggest that impaired functions of these receptors could be initiating and/or contributing factors in the progression of neurodegenerative processes.

\subsection{Human genetic association studies}

Roles of mutations and polymorphisms in genes for LXRs in the etiopathogenesis of human diseases corresponding to phenotypes observed in LXR-knockout mice, remain largely unexplored. The human gene encoding LXRa ( $L X R a, N R 1 H 3)$ is located on chromosome 11 , while the human gene encoding LXR $\beta$ $(L X R \beta, N R 1 H 2)$ is located on chromosome 19. According to data available at the National Center for Biotechnology Information (http:// www.ncbi.nlm.nih.gov/), both genes contain a number of single nucleotide polymorphisms (SNPs): 234 (41 in the coding region) and 130 (28 in the coding region) SNPs have been identified in $\angle X R a$ and $\angle X R \beta$ genes, respectively. Although many of these SNPs are located within the regulatory gene regions or represent missense variants, no data are currently

oxysterols or synthetic LXR agonists

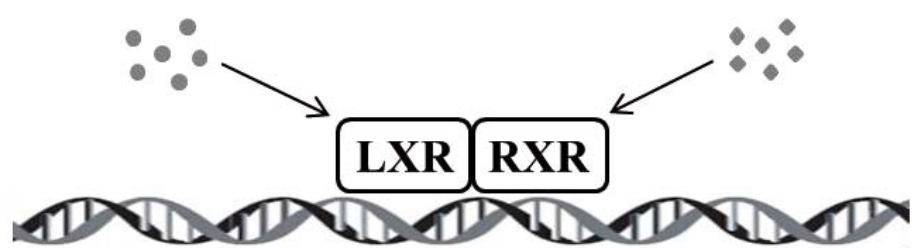

Gene transcription

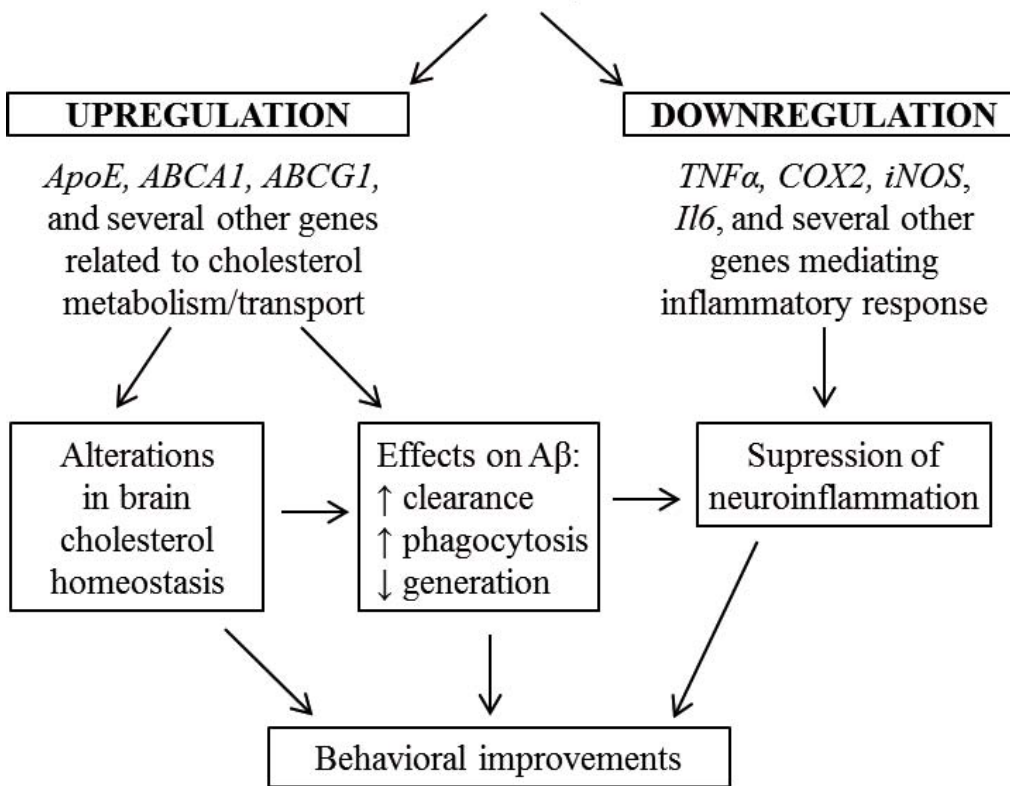

Figure 1. LXRs signaling targets brain cholesterol homeostasis, amyloid- $\beta(A \beta)$ pathology and neuroinflammation in AD mice. Activation of the DNA-bound LXR/RXR complex by natural or synthetic agonists of either partner alters transcriptional activity of target genes. Induction of cholesterol-related genes normalises brain cholesterol homeostasis and decreases brain $A \beta$ load, while suppression of pro-inflammatory genes reduces brain inflammation. The behavioural phenotype improves as the consequence of these biochemical changes. 
of Spanish origin, however, found no evidence for the association of rs2695121, rs 1052533 and rs1405655 genotypes or haplotypes with the sporadic AD [35]. No association between rs 1405655 and AD was found also in a Swedish population, although this study included only 86 AD patients and might have lacked statistical power to detect minor gene effects [36]. Two additional studies in a Spanish population investigated possible interactions of the $L X R \beta$ gene and other genes in determining the risk for sporadic $A D$. The first study, including 266 AD patients and 273 healthy controls, examined polymorphism rs1052533 in the $\angle X R \beta$ gene and polymorphism rs 2569190 in the gene encoding CD14, a surface receptor implicated in inflammatory response [37]. The results suggested that the two investigated polymorphisms might have combined effects on the susceptibility to sporadic AD. The second study, involving 414 AD patients and 442 healthy subjects, examined three SNPs (rs2695121, rs 1052533 and rs1405655) in the LXRK gene and one SNP (rs2071746) in the gene encoding heme oxygenase-1 (HO-1), an enzyme that stimulates oxidation of glial cholesterol to oxysterols [38]. The concomitant presence of the $\mathrm{HO}^{-1}$ risk genotype and any of the $L X R \beta$ risk genotypes was associated with a significantly increased risk of developing AD. Further association as well as functional studies are required to elucidate possible roles of $\angle X R a$ and $\angle X R \beta$ gene polymorphisms in the etiopathogenesis of sporadic AD.

\section{PHARMACOLOGICAL STUDIES LINKING LXRsTO MODULATION OF AD PATHOLOGY}

LXRs are physiologically activated by binding of certain oxidized derivatives of cholesterol (oxysterols) to their ligand-binding domain [12]. Some of the most potent endogenous agonists of LXRs include 22(R)-hydroxycholesterol, 24(S)-hydroxycholesterol (brain-specific cholesterol metabolite), 27-hydroxycholesterol, and 24(S),25-epoxycholesterol. In addition, a number of nutrition-derived oxysterols as well as synthetic compounds, the most common being T0901317 (TO90) and GW3965 (GW), have been recognised as potent ligands of $L X R s$
[39]. In vitro and in vivo studies performed over the last decade have shown that LXR activation by either natural or synthetic ligands exerts marked effects on gene expression in brain cells. Furthermore, evidence has been gathered for the beneficial effects of LXR agonists on cerebral cholesterol homeostasis, $A \beta$ levels, neuroinflammation, and, finally, behavioural performance in $A D$ model mice.

\subsection{Effects of LXR agonists cholesterol homeostasis}

Multiple lines of evidence suggest that alterations in cholesterol homeostasis are closely associated with the pathogenesis of AD [8,40-42]. Natural and synthetic agonists of LXRs were shown to up-regulate expression and activity of cholesterol-related genes, such as $A B C A 1, A B C G 1$, and apoE, in various types of brain cells, including neurones, astrocytes, microglia, oligodendrocytes, and brain capillary endothelial cells [43-51]. Concurrently, in vivo studies demonstrated increased levels of ABCA1, ABCG1, apoE, and Srebp1 in brains of mice treated with synthetic LXR agonists TO90 and GW $[31,43,46,52,53]$. In addition, Eckert et al. (2007) demonstrated that TO90-mediated induction of $A B C A 1, A B C G 1$ and apoE was accompanied by the decrease of cholesterol levels in cortical synaptosomal plasma membranes [53]. Furthermore, administration of TO90 to rats upregulated apoE and total cholesterol levels in cerebrospinal fluid (CSF), suggesting that LXR activation stimulates elimination of brain cholesterol via secretion of apoE-lipidated particles into the CSF [54]. Similarly to results on wild-type animals, synthetic LXR agonists elevated levels of $A B C A 1, A B C G 1$, apoE and Srebp1 also in brains of different animal models of $A D$ [32,46,55-61]. In addition, TO90 decreased membrane cholesterol levels [60] and increased levels of cholesterol precursors [61] in the brains of AD mice. Increased brain cholesterol excretion upon application of TO90 was demonstrated also in NPC mice [62]. Taken together, these studies suggest that brain-penetrable LXR agonists do regulate brain expression of genes related to cholesterol homeostasis and enhance brain cholesterol turnover under both physiological as well as pathological conditions.
3.2. Effects of $L X R$ agonists on $A \beta$ levels

$A \beta$ peptide, the main constituent of senile plaques found in brain parenchyma of $A D$ patients, is believed to play central role in the pathogenesis as well as therapy of $A D[6,63]$. $A \beta$ is formed during amyloidogenic processing of amyloid precursor protein (APP), by the successive action of $\beta$-secretase (BACE1) and presenilin (PSEN)-containing protease complex $\gamma$-secretase. APP can be processed also in a nonamyloidogenic pathway involving a-secretase in the first proteolytic step. Studies in different murine models of amyloidogenesis (summarised in Table 1) have consistently reported that synthetic LXR agonists decrease brain $A \beta$ burden $[32,56-60,64,65]$, the only exception being a study performed in aged APPSLXPS1 mut mice [61]. $A$ decrease in $A \beta$ levels was observed also in brains of wild-type mice [52] and rats [54] treated with TO90 for only 7 and 6 days, respectively. The outcome of most in vitro studies in neuronal and non-neuronal cellular models also demonstrated reducing effects of LXR agonists on $A \beta$ levels $[45,48,49,52,55,60,66]$. One study reported a modest increase rather than decrease in the secretion of $A \beta$ peptides [44]; the reasons for the discrepancy could be related to the experimental set-up and/or use of murine wild type APP (instead of the human Swedish mutant $A P P)$ as the source of $A \beta$ peptides. $A$ growing body of evidence suggests that the regulation of APP sorting/processing pathways is linked to cellular cholesterol levels and/or distribution (for review see $[8,68]$ ). Mechanisms by which LXRs regulate APP metabolism remain somewhat controversial, with studies reporting both cholesterol efflux-dependent as well as -independent effects of LXR agonists on $A \beta$ levels [52,55,67]. Furthermore, some studies suggest that LXR agonists shift APP processing from $\beta$ - to $\alpha$-secretase cleavage influencing thus $A \beta$ generation $[49,60,64,69]$, while others argue that LXR agonists increase $A \beta$ clearance or degradation rather than its production $[32,57,58,70]$. Recent in vivo data obtained using different doses of LXR agonist GW [59] along with our in vitro results [71] are indicative of a dose-effect of LXR agonists on APP processing, with only higher concentrations being able to decrease $A \beta$ generation. 
Table 1. Effects of synthetic LXR agonists on brain A $\beta$ levels and behavior in mouse models of AD.

\begin{tabular}{|c|c|c|c|c|c|c|c|}
\hline $\begin{array}{l}\text { Mouse } \\
\text { line }\end{array}$ & $\begin{array}{l}\text { Animals } \\
\text { age }\end{array}$ & $\begin{array}{c}\text { Treatment } \\
\text { duration }\end{array}$ & $\begin{array}{l}\text { LXR } \\
\text { agonist }\end{array}$ & $\begin{array}{c}\text { Dose } \\
\text { (mg/kg/day) }\end{array}$ & $\begin{array}{c}\text { Effects on } \\
\text { brain } A \beta \text { levels }\end{array}$ & $\begin{array}{l}\text { Effects on } \\
\text { behavior }\end{array}$ & Year of publication \\
\hline APP23 & 11 weeks & 6 days & TO90 & 50 & $\downarrow A \beta 40, A \beta 42$ & not assessed & 2005 [55] \\
\hline APP23 & 6 months & 4 weeks & T090 & 20 & $\downarrow$ insoluble $A \beta$ & not assessed & $2007[56]$ \\
\hline $\operatorname{Tg} 2576$ & 5 months & 7 days & TO90 & 30 or 50 & $\downarrow A \beta 42$ in hippocampus & $\begin{array}{l}\text { improvement in contextual fear } \\
\text { conditioning task }\end{array}$ & $2007[57]$ \\
\hline $\operatorname{Tg} 2576$ & 5 months & 6 days & GW & 50 & not assessed & $\begin{array}{l}\text { improvement in contextual fear } \\
\text { conditioning task }\end{array}$ & 2008 [58] \\
\hline $\operatorname{Tg} 2576$ & 12 months & 4 months & GW & 33 & $\begin{array}{l}\downarrow A \beta 40, A \beta 42 \\
\downarrow A \beta \text { plaque load }\end{array}$ & not assessed & $2008[58]$ \\
\hline APP/PS1 & 8 months & 8 weeks & GW & 2.5 or 33 & $\begin{array}{l}\text { a trend toward reduced } \\
\text { amyloid load }\end{array}$ & $\begin{array}{l}\text { improvements in object recognition } \\
\text { and Morris water maze tasks }\end{array}$ & 2010 [59] \\
\hline APP23 & 13 months & 7 weeks & TO90 & 50 & $\downarrow A \beta$ in ISF & $\begin{array}{l}\text { slight improvement in spatial learning } \\
\text { in Morris water maze }\end{array}$ & $2011[32]$ \\
\hline APP/PS1 & 8 months & 12 days & TO90 & 30 & $\begin{array}{l}\downarrow A \beta 40, A \beta 42 \\
\downarrow A \beta \text { plaque area }\end{array}$ & not assessed & $2011[60]$ \\
\hline $\begin{array}{l}\text { APPSL } \\
\text { xPS1mut }\end{array}$ & 21 months & 6-9 weeks & TO90 & 30 & no effect on $A \beta$ plaque load & $\begin{array}{l}\text { improvement in object } \\
\text { location and recognition tasks }\end{array}$ & $2011[61]$ \\
\hline APP/PS1 & 6 months & 30 days & TO90 & 30 & $\begin{array}{l}\downarrow A \beta 42 \\
\downarrow A \beta \text { plaque area }\end{array}$ & $\begin{array}{l}\text { improvement in Morris water maze } \\
\text { performance }\end{array}$ & 2012 [65] \\
\hline
\end{tabular}

APP23 - mouse expressing human APP751 isoform containing the Swedish (K670N/M671C) familial AD mutation; Tg2576 - mouse expressing human APP695 isoform containing the Swedish (K670N/M671C) familial AD mutation; APP/PS1 - mouse coexpressing a chimeric human/mouse APP650 isoform containing the Swedish (K670N/M671C) familial AD mutation and the human PS1 gene deleted for exon 9; APPSLXPS1 mut - mouse coexpressing human APP gene carrying the Swedish/London familial AD mutations and mutant PS1 (M146L); TO90 - TO901317; GW - GW3965.

\subsection{Effects of LXR agonists on} neuroinflammation

Ample evidence suggests that brain inflammation plays an important role in the pathogenesis of $A D$ (for reviews see [72-74]). A number of inflammatory markers have been associated with $A D$, including the accumulation of activated microglia and elevation of inflammatory mediators such as inducible nitric oxide synthase (iNOS) and cyclooxygenase-2 (COX-2). LXRs were shown to regulate inflammatory gene expression in several tissues and cell types through the unique mechanism of transrepression $[18,75,76]$. In vitro studies have demonstrated that LXR agonists inhibit lipopolysaccharide (LPS)-, IFN-g-, or A 3 -induced inflammatory responses in primary microglia and astrocytes by reducing nitric oxide release and expression of various proinflammatory molecules including iNOS, COX-2, tumor necrosis factor-alpha (TNF-a), IL-1, IL-
6, interferon-beta, interferon regulatory factor-1, monocyte chemoattractant protein-1 (MCP-1) and others [31,56,65,77-80]. In addition, treatment of immortalised murine microglial cells with the synthetic LXR agonist GW was shown to reverse LPSinduced inhibition of $A \beta$ phagocytosis [31]. In vivo studies demonstrated that LXR agonists GW or TO90 reduce the neuroinflammatory response in experimental stroke [81], NPC mice [62], and in two lines of $A D$ mice, i.e. APP23 [56] and APP/PS1 [65]. In addition, administration of TO90 to APP/PS1 mice significantly decreased microglial activation [65]. Both in vitro and in vivo data suggested that LXR agonists suppress the production of proinflammatory molecules in brain cells by inhibiting nuclear factor-kappa B (NF-kB) DNA-binding activity $[65,79]$. Collectively, these results indicate that LXR agonists could alleviate $A D$ pathology by acting on the brain inflammatory response.

\subsection{Effects of LXR agonists on} cognitive functions in AD mice

Memory loss is the earliest and the most common clinical manifestation of $A D$ [82]. Mice overexpressing mutant APP and/or presenilins develop, along with AD-like neuropathology, also age-related memory deficits [83]. Different studies have shown that administration of synthetic LXR agonists restores behavioural phenotype in these animals. In particular, short-term administration of TO90 or GW (7 or 6 days, respectively) $[57,58]$ to $\operatorname{Tg} 2576$ mice restored contextual memory, as demonstrated by improved performance in contextual fear conditioning task. Long-term (8 weeks) treatment of APP/PS1 mice with GW completely restored object recognition memory and improved performance in Morris water maze tasks [59]. Long-term (6-9 weeks) application of TO90 restored object recognition and object location memory also in aged APPSLXPS1 mice [61], and slightly improved spatial learning in 
aged APP23 mice [32]. Improvement in Morris water maze tasks was obtained also in APP/PS1 mice treated for 30 days with TO90 [65]. TO90 administration was further shown to reduce memory deficits caused by high-fat diet in APP23 mice [70].

\section{MOVING OF LXR AGONISTS TO CLINICAL PRACTICE}

In spite of favourable effects demonstrated in $A D$ mice (summarised in Figure 1), moving of LXR agonists to clinical practice has been hampered owning to adverse side effects, the most serious being hepatic steatosis and increased production of atherogenic triacylglycerol-rich VLDL particles [84]. LXRs form permissive heterodimers with retinoid $X$ receptors (RXRs), the receptors of 9-cisretinoid acid [85]. Binding of agonists to either member of the LXR/RXR complex facilitates exchange of co-repressors with co-activators and subsequently induces transcriptional activity of the target genes (see ref. [20] for details). Therefore, activation of LXR-regulated pathways using RXR agonists appeared as promising approach to circumvent undesirable effects of the currently available LXR agonists. Indeed, Cramer et al. (2012) reported recently that administration of the RXR agonist bexarotene to APP/PS1 mice reversed cognitive impairments, decreased soluble $A \beta$ levels and most strikingly, reduced $A \beta$ plaque area for $50 \%$ within only 72 hours [86]. Unfortunately, none of the follow-up studies could replicate the effect of bexarotene on $A \beta$ plaques [87-90] and only two out of four were able to confirm the effect on soluble $A \beta$ levels $[87,90]$, one of them reproducing also cognitive improvements [87]. However, the FDA-approved formulation of bexarotene, Targretin, has entered phases I and II clinical trials in AD patients [91], regardless of this inconstancy in preclinical results.

\section{CONCLUSIONS}

Genetic deletion studies in mice have provided clear evidence for the role of LXR in AD-related pathological processes. On the other hand, a potential contribution of genetic variants in human LXR genes to the etiopathogenesis of $A D$ remains controversial and further genetic association as well as functional studies are warranted. LXR directly regulate multiple genes involved in lipid/cholesterol homeostasis and immune cell function, both of which seem to be disturbed in AD. Outcomes of pharmacological studies in different in vitro and in vivo models of $A D$ strongly suggest that activation of LXR-regulated pathways might be a promising approach to modulate or even cure $A D$ (Figure 1). Most of this research has been done in mice or mouse-derived cells, with only occasional exceptions [e.g. 47-49,69]. It has been observed that some aspects of LXR physiology differ between humans and rodents [92,93]. In order to fully understand effects of LXR agonists and modulators on $A D$ pathogenesis, further studies are needed, particularly in experimental models more relevant to human physiology.

\section{ACKNOWLEDGMENTS}

Authors' research is supported by the Croatian Ministry of Science, Education and Sport (grants 098-1081870-2395 and 108-1081870-1942), the Austrian Science Fund (grants W1226-B18 and P24783-B19), the Croatian Science Foundation (grant 09/16) and $\mathrm{NIH}$ grant P50 AG005138. All authors participated in writing and the critical review of the manuscript.

References

[1] Lim A., Tsuang D., Kukull W., Nochlin D., Leverenz J., McCormick W., et al., Clinico-neuropathological correlation of Alzheimer's disease in a community-based case series, J. Am. Geriatr., 1999, 47, 564-569

[2] Alzheimer's Association, 2009 Alzheimer's disease facts and figures, Alzheimers Dement., 2009, 5, 234-270

[3] Barnes D.E., Yaffe K., The projected effect of risk factor reduction on Alzheimer's disease prevalence, Lancet Neurol., 2011, 10, 819-828

[4] Olgiati P., Politis A.M., Papadimitriou G.N., De Ronchi D., Serretti A., Genetics of late-onset Alzheimer's disease: update from the alzgene database and analysis of shared pathways, Int. J. Alzheimers Dis., 2011, 2011, 832379

[5] Jones L., Holmans P.A., Hamshere M.L., Harold D., Moskvina V., Ivanov D., et al., Genetic evidence implicates the immune system and cholesterol metabolism in the aetiology of Alzheimer's disease, PLoS One, 2010, 5, e13950

[6] Palop J.J., Mucke L., Amyloid-beta-induced neuronal dysfunction in Alzheimer's disease: from synapses toward neural networks, Nat. Neurosci., 2010, 13, 812-818

[7] Šimić G., Stanić G., Mladinov M., Jovanov-Milošević N., Kostović I., Hof P.R., Does Alzheimer's disease begin in the brainstem?, Neuropathol. Appl. Neurobiol., 2009, 35, 532-554
[8] Di Paolo G., Kim T.W., Linking lipids to Alzheimer's disease: cholesterol and beyond, Nat. Rev. Neurosci., 2011, 12, 284-296

[9] Heneka M.T., O'Banion M.K., Terwel D., Kummer M.P., Neuroinflammatory processes in Alzheimer's disease, J. Neural Transm., 2010, 117, 919-947

[10] Citron M., Alzheimer's disease: strategies for disease modification, Nat. Rev. Drug Discov., 2010, 9, 387-398

[11] Zhang Z.D., Burch P.E., Cooney A.J., Lanz R.B., Pereira F.A., Wu J.Q., et al., Genomic analysis of the nuclear receptor family: New insights into structure, regulation, and evolution from the rat genome, Genome Res., 2004, 14, 580-90

[12] Janowski B.A., Willy P.J., Devi T.R., Falck J.R., Mangelsdorf D.J., An oxysterol signalling pathway mediated by the nuclear receptor LXR alpha, Nature, 1996, 383, 728-731

[13]Apfel R., Benbrook D., Lernhardt E., Ortiz M.A., Salbert G., Pfahl M., A novel orphan receptor-specific for a subset of thyroid hormone-responsive elements and its interaction with the retinoid/thyroid hormone-receptor subfamily, Mol. Cell. Biol., 1994, 14, 7025-7035

[14] Hu Y-W., Zheng L., Wang Q., Regulation of cholesterol homeostasis by liver X receptors, Clin. Chim. Acta, 2010, 411, 617-625 
[15] Zhao C., Dahlman-Wright K., Liver $X$ receptor in cholesterol metabolism, J. Endocrinol., 2010, 204, 233-240

[16] Calayir E., Becker T., Kratzer A., Ebner B., Panzenbock U., Stefujl J., et al., LXR-agonists regulate apoM expression differentially in liver and intestine, Curr. Phar. Biotechnol., 2008, 9, 516-521

[17] Stefulj J., Panzenboeck U., Becker T., Hirschmugl B., Schweinzer C., Lang I., et al., Human Endothelial Cells of the Placental Barrier Efficiently Deliver Cholesterol to the Fetal Circulation via $A B C A 1$ and ABCG1, Circ. Res., 2009, 104, 600-608

[18] Joseph S.B., Castrillo A., Laffitte B.A., Mangelsdorf D.J., Tontonoz P., Reciprocal regulation of inflammation and lipid metabolism by liver $X$ receptors, Nat. Med., 2003, 9, 213-219

[19] Mitro N., Mak P.A., Vargas L., Godio C., Hampton E., Molteni V., et al., The nuclear receptor LXR is a glucose sensor, Nature, 2007, 445, 219223

[20] Jakobsson T., Treuter E., Gustafsson J.A., Steffensen K.R., Liver X receptor biology and pharmacology: new pathways, challenges and opportunities, Trends Pharmacol. Sci., 2012, 33, 394-404

[21] Kim W.S., Bhatia S., Elliott D.A., Agholme L., Kågedal K., McCann H., et al., Increased ATP-binding cassette transporter A1 expression in Alzheimer's disease hippocampal neurons, J. Alzheimers Dis., 2010, 21, 193-205

[22] Akram A., Schmeidler J., Katsel P., Hof P.R., Haroutunian V., Association of ApoE and LRP mRNA levels with dementia and AD neuropathology, Neurobiol. Aging, 2012, 33, 628.e1-14

[23] Akram A., Schmeidler J., Katsel P., Hof P.R., Haroutunian V., Increased expression of cholesterol transporter $A B C A 1$ is highly correlated with severity of dementia in AD hippocampus, Brain Res., 2010, 1318, 167-177

[24] Vuletic S., Jin L.W., Marcovina S.M., Peskind E.R., Moller T., Albers J.J., Widespread distribution of PLTP in human CNS: evidence for PLTP synthesis by glia and neurons, and increased levels in Alzheimer's disease, J. Lipid Res., 2003, 44, 1113-1123

[25] Wahrle S.E., Jiang H., Parsadanian M., Hartman R.E., Bales K.R., Paul S.M., et al., Deletion of Abca1 increases Abeta deposition in the PDAPP transgenic mouse model of Alzheimer disease, J. Biol. Chem., 2005, 280, 43236-43242

[26] Wahrle S.E., Jiang H., Parsadanian M., Kim J., Li A.M., Knoten A., et al., Overexpression of ABCA1 reduces amyloid deposition in the PDAPP mouse model of Alzheimer disease, J. Clin. Invest., 2008, 118, 671-682

[27] Kim J., Jiang H., Park S., Eltorai A.E.M., Stewart F.R., Yoon H., et al., Haploinsufficiency of human APOE reduces amyloid deposition in a mouse model of amyloid-beta amyloidosis, J. Neurosci., 2011, 31, 18007-18012

[28] Wang L., Schuster G.U., Hultenby K., Zhang Q.H., Andersson S., Gustafsson J.A., Liver $X$ receptors in the central nervous system: From lipid homeostasis to neuronal degeneration, Proc. Natl. Acad. Sci. USA, 2002, 99, 3878-13883

[29] Andersson S., Gustafsson N., Warner M., Gustafsson J.A., Inactivation of liver $X$ receptor beta leads to adult-onset motor neuron degeneration in male mice, Proc. Natl. Acad. Sci. USA, 2005, 102, 3857-3862
[30] Fan X., Kim H-J., Bouton D., Warner M., Gustafsson J-A., Expression of liver $\mathrm{X}$ receptor beta is essential for formation of superficial cortical layers and migration of later-born neurons, Proc. Natl. Acad. Sci. USA, 2008, 105, 13445-13450

[31] Zelcer N., Khanlou N., Clare R., Jiang Q., Reed-Geaghan E.G., Landreth G.E., et al., Attenuation of neuroinflammation and Alzheimer's disease pathology by liver $x$ receptors, Proc. Natl. Acad. Sci. U. S. A., 2007, 104, 10601-10606

[32] Terwel D., Steffensen K.R., Verghese P.B., Kummer M.P., Gustafsson J.A., Holtzman D.M., et al., Critical role of astroglial apolipoprotein $E$ and liver $\mathrm{X}$ receptor-alpha expression for microglial Abeta phagocytosis, J. Neurosci., 2011, 31, 7049-7059

[33] Liu B., Li H., Repa J.J., Turley S.D., Dietschy J.M., Genetic variations and treatments that affect the lifespan of the NPC1 mouse, J. Lipid Res., 2008, 49, 663-669

[34] Adighibe O., Arepalli S., Duckworth J., Hardy J., Wavrant-De Vrieze F., Genetic variability at the LXR gene (NR1H2) may contribute to the risk of Alzheimer's disease, Neurobiol. Aging, 2006, 27, 1431-1434

[35] Rodriguez-Rodriguez E., Llorca J., Mateo I., Infante J., SanchezQuintana C., Garcia-Gorostiaga I., et al., No association of genetic variants of liver X receptor-beta with Alzheimer's disease risk, Am. J. Med. Genet. B.Neuropsychiatr. Genet., 2008, 147B, 650-653

[36] Giedraitis V., Kilander L., Degerman-Gunnarsson M., Sundelof J., Axelsson T., Syvanen A.C., et al., Genetic analysis of Alzheimer's disease in the Uppsala Longitudinal Study of Adult Men, Dement. Geriatr. Cogn. Disord., 2009, 27, 59-68

[37] Rodriguez-Rodriguez E., Sanchez-Juan P., Mateo I., Infante J., SanchezQuintana C., Garcia-Gorostiaga I., et al., Interaction between CD14 and LXR beta genes modulates Alzheimer's disease risk, J. Neurol. Sci., 2008, 264, 97-99

[38] Infante J., Rodriguez-Rodriguez E., Mateo I., Llorca J., VazquezHiguera J.L., Berciano J., et al., Gene-gene interaction between heme oxygenase- 1 and liver $\mathrm{X}$ receptor-beta and Alzheimer's disease risk, Neurobiol. Aging, 2010, 31, 710-714

[39] Viennois E., Mouzat K., Dufour J., Morel L., Lobaccaro J.M., Baron S., Selective liver $X$ receptor modulators (SLiMs): What use in human health?, Mol. Cell. Endocrinol., 2012, 351, 129-141

[40] Leduc V., Jasmin-Belanger S., Poirier J., APOE and cholesterol homeostasis in Alzheimer's disease, Trends Mol. Med., 2010, 16, 469477

[41] Martins I.J., Berger T., Sharman M.J., Verdile G., Fuller S.J., Martins R.N., Cholesterol metabolism and transport in the pathogenesis of Alzheimer's disease, J. Neurochem., 2009, 111, 1275-1308

[42] Gamba P., Testa G., Sottero B., Gargiulo S., Poli G., Leonarduzzi G., The link between altered cholesterol metabolism and Alzheimer's disease, Ann. NY Acad. Sci., 2012, 1259, 54-64

[43] Whitney K.D., Watson M.A., Collins J.L., Benson W.G., Stone T.M., Numerick M.J., et al., Regulation of cholesterol homeostasis by the liver $\mathrm{X}$ receptors in the central nervous system, Mol. Endocrinol., 2002, 16, 1378-1385

[44] Fukumoto H., Deng A., Irizarry M.C., Fitzgerald M.L., Rebeck G.W., Induction of the cholesterol transporter $A B C A 1$ in central nervous 
system cells by liver $X$ receptor agonists increases secreted Abeta levels, J. Biol. Chem., 2002, 277, 48508-48513

[45] Koldamova R.P., Lefterov L.M., Ikonomovic M.D., Skoko J., Lefterov P.I., Isanskis B.A., et al., 22R-Hydroxycholesterol and 9-cis-retinoic acid induce ATP-binding cassette transporter A1 expression and cholesterol efflux in brain cells and decrease amyloid beta secretion, J. Biol. Chem., 2003, 278, 13244-13256

[46] Liang Y., Lin S.Z., Beyer T.P., Zhang Y.Y., Wu X., Bales K.R., et al., A liver $X$ receptor and retinoid $X$ receptor heterodimer mediates apolipoprotein E expression, secretion and cholesterol homeostasis in astrocytes, J. Neurochem., 2004, 88, 623-634

[47] Abildayeva K., Jansen P.J., Hirsch-Reinshagen V., Bloks V.W., Bakker A.H.F., Ramaekers F.C.S., et al., 24(S)-hydroxycholesterol participates in a liver $\mathrm{X}$ receptor-controlled pathway in astrocytes that regulates apolipoprotein E-mediated cholesterol efflux, J. Biol. Chem., 2006, 281, 12799-12808

[48] Kim W.S., Chan S.L., Hill A.F., Guillemin G.J., Garner B., Impact of 27-hydroxycholesterol on amyloid-beta peptide production and ATP-binding cassette transporter expression in primary human neurons, J. Alzheimers Dis., 2009, 16, 121-131

[49] Prasanthi J.R.P., Huls A., Thomasson S., Thompson A., Schommer E., Ghribi O., Differential effects of 24-hydroxycholesterol and 27-hydroxycholesterol on beta-amyloid precursor protein levels and processing in human neuroblastoma SH-SY5Y cells, Mol. Neurodegener., 2009, 4, 1

[50] Nelissen K., Mulder M., Smets I., Timmermans S., Smeets K., Ameloot $M$., et al., Liver $X$ receptors regulate cholesterol homeostasis in oligodendrocytes, J. Neurosci. Res., 2012,90, 60-71

[51] Panzenboeck U., Kratzer I., Sovic A., Wintersperger A., Bernhart E., Harnmer A., et al., Regulatory effects of synthetic liver $X$ receptorand peroxisome-proliferator activated receptor agonists on sterol transport pathways in polarized cerebrovascular endothelial cells, Int. J. Biochem. Cell Biol., 2006, 38, 1314-1329

[52]Burns M.P., Vardanian L., Pajoohesh-Ganji A., Wang L.L., Cooper M., Harris D.C., et al., The effects of ABCA1 on cholesterol efflux and Abeta levels in vitro and in vivo, J. Neurochem., 2006, 98, 792-800

[53] Eckert G.P., Vardanian L., Rebeck G.W., Burns M.P., Regulation of central nervous system cholesterol homeostasis by the liver $\mathrm{X}$ receptor agonist TO-901317, Neurosci. Lett., 2007, 423, 47-52

[54] Suon S., Zhao J., Villarreal S.A., Anumula N., Liu M.L., Carangia L.M., et al., Systemic treatment with liver $X$ receptor agonists raises apolipoprotein $\mathrm{E}$, cholesterol, and amyloid-beta peptides in the cerebral spinal fluid of rats, Mol. Neurodegener. 2010, 5, 44

[55] Koldamova R.P., Lefterov I.M., Staufenbiel M., Wolfe D., Huang S., Glorioso J.C., et al., The liver $\mathrm{X}$ receptor ligand T0901317 decreases amyloid beta production in vitro and in a mouse model of Alzheimer's disease, J. Biol. Chem., 2005, 280, 4079-4088

[56] Lefterov I., Bookout A., Wang Z., Staufenbiel M., Mangelsdorf D., Koldamova R., Expression profiling in APP23 mouse brain: inhibition of $A$ beta amyloidosis and inflammation in response to LXR agonist treatment, Mol. Neurodegener., 2007, 2, 20
[57] Riddell D.R., Zhou H., Comery T.A., Kouranova E., Lo C.F., Warwick H.K., et al., The LXR agonist TO901317 selectively lowers hippocampal A beta 42 and improves memory in the Tg2576 mouse model of Alzheimer's disease, Mol. Cell. Neurosci., 2007, 34, 621-628

[58] Jiang Q., Lee C.Y.D., Mandrekar S., Wilkinson B., Cramer P., Zelcer N., et al., ApoE promotes the proteolytic degradation of A beta, Neuron, $2008,58,681-693$

[59]Donkin J.J., Stukas S., Hirsch-Reinshagen V., Namjoshi D., Wilkinson A., May S., et al., ATP-binding cassette transporter A1 mediates the beneficial effects of the liver $X$ receptor agonist GW3965 on object recognition memory and amyloid burden in amyloid precursor protein/presenilin 1 Mice, J. Biol. Chem., 2010, 285, 34144-34154

[60] Cui W.G., Sun Y., Wang Z.P., Xu C.C., Xu L., Wang F., et al., Activation of liver $X$ receptor decreases BACE1 expression and activity by reducing membrane cholesterol levels, Neurochem. Res., 2011, 36, 1910-1921

[61] Vanmierlo T., Rutten K., Dederen J., Bloks V.W., van Vark-van der Zee L.C., Kuipers F., et al., Liver $\mathrm{X}$ receptor activation restores memory in aged AD mice without reducing amyloid, Neurobiol. Aging, 2011, 32, 1262-1272

[62] Repa J.J., Li H., Frank-Cannon T.C., Valasek M.A., Turley S.D., Tansey M.G., et al., Liver $X$ receptor activation enhances cholesterol loss from the brain, decreases neuroinflammation, and increases survival of the NPC1 mouse, J. Neurosci., 2007, 27, 14470-14480

[63] Karran E., Mercken M., De Strooper B., The amyloid cascade hypothesis for Alzheimer's disease: an appraisal for the development of therapeutics, Nat. Rev. Drug Discov., 2011, 10, 698-712

[64] Koldamova T., Lefterov I.M., Staufenbiel M., Wolfe D., Huang S.H., Glorioso J.C., et al., The liver X receptor ligand T0901317 decreases amyloid beta production in vitro and in a mouse model of Alzheimer's disease, J. Biol. Chem., 2005, 280, 4079-4088

[65] Cui W., Sun Y., Wang Z., Xu C., Peng Y., Li R., Liver X receptor activation attenuates inflammatory response and protects cholinergic neurons in APP/PS1 transgenic mice, Neuroscience, 2012, 210, 200-210

[66] Sun Y., Yao J., Kim T.W., Tall A.R., Expression of liver X receptor target genes decreases cellular amyloid beta peptide secretion, J. Biol. Chem., 2003, 278, 27688-27694

[67] Czech C., Burns M.P., Vardanian L., Augustin A., Jacobsen H., Baumann K., et al., Cholesterol independent effect of LXR agonist TO-901317 on gamma-secretase, J. Neurochem., 2007, 101, 929-936

[68] Burns M.P., Rebeck G.W., Intracellular cholesterol homeostasis and amyloid precursor protein processing, Biochim. Biophys. Acta, 2010, 1801, 853-859

[69] Schweinzer C., Kober A., Lang I., Etschmaier K., Scholler M., Kresse A., et al., Processing of endogenous A $\beta P P$ in blood-brain barrier endothelial cells is modulated by liver- $X$ receptor agonists and altered cellular cholesterol homeostasis, J. Alzheimers Dis., 2011, 27, 341-360

[70] Fitz N.F., Cronican A., Pham T., Fogg A., Fauq A.H., Chapman R., et al., Liver $\mathrm{X}$ receptor agonist treatment ameliorates amyloid pathology and memory deficits caused by high-fat diet in APP23 mice, J. Neurosci., 2010, 30, 6862-6872 
[71] Štefulj J., Perić M., Malnar M., Košiček M., Schweinzer C, Živković J., et al., Pharmacological activation of $L X R s$ decreases amyloid- $\beta$ levels in Niemann-Pick type C model cells, 2013, Curr. Pharm. Biotechnol., 5, (in press)

[72] Akiyama H., Barger S., Barnum S., Bradt B., Bauer J., Cole G.M., et al., Inflammation and Alzheimer's disease, Neurobiol. Aging, 2000, 21, 383-421

[73] Lee Y.J., Han S.B., Nam S.Y., Oh K.W., Hong J.T., Inflammation and Alzheimer's Disease, Arch. Pharm. Res., 2010, 33, 1539-1556

[74] Tuppo E.E., Arias H.R., The role of inflammation in Alzheimer's disease, Int. J. Biochem. Cell Biol., 2005, 37, 289-305

[75] Bensinger S.J., Tontonoz P., Integration of metabolism and inflammation by lipid-activated nuclear receptors, Nature, 2008, 454, 470-477

[76] Zelcer N., Tontonoz P., Liver X receptors as integrators of metabolic and inflammatory signaling, J. Clin. Invest., 2006, 116, 607-614

[77]Lee C.S., Joe E.H., Jou I., Oxysterols suppress inducible nitric oxide synthase expression in lipopolysaccharide-stimulated astrocytes through liver $X$ receptor, Neuroreport, 2006, 17, 183187

[78] Kim O.S., Lee C.S., Joe E.H., Jou I., Oxidized low density lipoprotein suppresses lipopolysaccharide-induced inflammatory responses in microglia: oxidative stress acts through control of inflammation, Biochem. Biophys. Res. Commun., 2006, 342, 9-18

[79] Zhang-Gandhi C.X., Drew P.D., Liver X receptor and retinoid X receptor agonists inhibit inflammatory responses of microglia and astrocytes, J. Neuroimmunol., 2007, 183, 50-59

[80] Lee J.H., Park S.M., Kim O.S., Lee C.S., Woo J.H., Park S.J., et al., Differential SUMOylation of LXRalpha and LXRbeta mediates transrepression of STAT1 inflammatory signaling in IFN-gammastimulated brain astrocytes, Mol. Cell, 2009, 35, 806-817

[81] Morales J.R., Ballesteros I., Deniz J.M., Hurtado O., Vivancos J., Nombela F., et al., Activation of liver $\mathrm{X}$ receptors promotes neuroprotection and reduces brain inflammation in experimental stroke, Circulation, 2008, 118, 1450-1459

[82] Alzheimers A., 2012 Alzheimer's disease facts and figures, Alzheimers Dement., 2012, 8, 131-168

[83] Spires T.L., Hyman B.T., Transgenic models of Alzheimer's disease: learning from animals, NeuroRx, 2005, 2, 423-437
[84] Grefhorst A., Elzinga B.M., Voshol P.J., Plösch T., Kok T., Bloks V.W., et al., Stimulation of lipogenesis by pharmacological activation of the liver $\mathrm{X}$ receptor leads to production of large, triglyceride-rich very low density lipoprotein particles, J. Biol. Chem., 2002, 277, 34182-34190

[85] Willy P.J., Mangelsdorf D.J., Unique requirements for retinoid dependent transcriptional activation by the orphan receptor LXR, Genes Dev., 1997, 11, 289-298

[86] Cramer P.E., Cirrito J.R., Wesson D.W., Lee C.Y.D., Karlo J.C., Zinn A.E., et al., ApoE-directed therapeutics rapidly clear $\beta$-amyloid and reverse deficits in AD mouse models, Science, 2012, 335, 1503-1506

[87] Fitz N.F., Cronican A.A., Lefterov I., Koldamova R., Comment on “ApoEdirected therapeutics rapidly clear $\beta$-amyloid and reverse deficits in AD mouse models", Science, 2013, 340, 924-c

[88] Price A.R., Xu G.L., Siemienski Z.B., Smithson L.A., Borchelt D.R., Golde T.E., et al., Comment on "ApoE-directed therapeutics rapidly clear $\beta$-amyloid and reverse deficits in AD mouse models ", Science, 2013, $340,924-d$

[89] Tesseur I., Lo A.C., Roberfroid A., Dietvorst S., Van Broeck B., Borgers $M$., et al., Comment on "ApoE-directed therapeutics rapidly clear $\beta$-amyloid and reverse deficits in AD mouse models ", Science, 2013, 340, 924-e

[90] Veeraraghavalu K., Zhang C., Miller S., Hefendehl J.K., Rajapaksha T.W., Ulrich J., et al., Comment on "ApoE-directed therapeutics rapidly clear $\beta$-amyloid and reverse deficits in AD mouse models", Science, 2013, 340, 924-f

[91] Landreth G.E., Cramer P.E., Lakner M.M., Cirrito J.R., Wesson D.W., Brunden K.R., et al., Response to Comments on "ApoE-directed therapeutics rapidly clear $\beta$-amyloid and reverse deficits in $A D$ mouse models", Science, 2013, 340, 924-g

[92] Rigamonti E., Helin L., Lestavel S., Mutka A. L., Lepore M., Fontaine C., et al., Liver $X$ receptor activation controls intracellular cholesterol trafficking and esterification in human macrophages, Circ. Res., 2005, 97, 682-689

[93] Kotokorpi P., Ellis E., Parini P., Nilsson L.M., Strom S., Steffensen K.R., et al., Physiological differences between human and rat primary hepatocytes in response to liver $\mathrm{X}$ receptor activation by 3-[3-[N-(2-chloro-3-trifluoromethylbenzyl)-(2,2-diphenylethyl) amino]propyloxy]phenylacetic acid hydrochloride (GW3965), Mol. Pharmacol., 2007, 72, 947-955 